\title{
Research on College English Teaching Under the Thinking Mode of "Internet Plus"
}

\author{
Cong Wu \\ Sichuan Vocational College of Information Technology, Sichuan 628017, China \\ tracey_wu@163.com
}

Keywords: Internet plus education; thinking mode; college English.

\begin{abstract}
The background of "Internet plus" social era is continuously applied to the education. Among them, the teaching mode of "Internet plus education" is continuously and strongly involved in the traditional education mode. Such teaching mode can be applied to the teaching mode of college English in our country to develop towards more effective and convenient direction by means of the tool of Internet. This paper researched on the basic orientation of Chinese national English teaching mode from the perspective of "Internet plus education" and primarily discussed the strategies of college English teaching mode from this aspect.
\end{abstract}

\section{Introduction}

There are many disadvantages in traditional college English teaching. It is relatively backward both on the teaching content of the university and the way of teaching. By this way, college students' enthusiasm will be restrained, which is not conducive to the learning environment of English learning. Under such circumstance, it has become the opportunity and challenge for most English teachers in national colleges and universities that how to reform English teaching mode in our country to adapt to the need of "Internet plus" ideology. Therefore, colleges and universities should use the information technology provided by "Internet plus" ideas in a certain situation to make corresponding in-depth integration with English teaching. In this way, we can actively promote the reform and innovation in the English teaching mode of colleges and universities and constantly improve the English teaching level in colleges and universities.

\section{The Idea of "Internet Plus Education"}

Under the background of the great era of "Internet plus" in our country, the continuous development and innovation of mobile Internet, big data and cloud computing are impacting the traditional teaching mode, which has brought profound meaning. Under the idea of "Internet plus education", universities can make use of relevant information communication technology and Internet platform to realize the integration of the Internet and traditional education industry and make the convergence of a deeper integration, which can create and develop the new ecology in education. With the promotion and development of "Internet + education", the emergence of some new education products such as the micro-course, flipped classroom and mobile classroom in daily life, has made online learning a more rapid trend and make a considerable impact and reconstruction on the traditional offline education. Thus it can be seen that "Internet + education" in the English teaching of colleges and universities is not only the Internet technology bringing some innovation to education technology, but great impacting on students' learning and teachers' teaching and organization model as well as create more profound thoughts with national education system to some extent.

\section{3. "Internet Plus" and College English Teaching}

In current society, we can connect and communicate with our Internet technology from all aspects on the basis of "Internet plus", changeable era and continuous development of society. At the same time, special consideration should be given to the continuous improvement of BAT as the relative 
representative and the company of e-commerce in China. By this way, the resources of the Internet can deeply integrate with the real economic development, which is closely related to people's daily life in the technology of the Internet. And it exists the congenital advantage in the face of the assembling resources of the Internet and allocating resources. At present, English teachers in colleges and universities of our country should be to open fully, and they are required to open the relevant ideas in our Internet industry under the constant developing era. Closely connect Chinese Internet with real life to constantly promote the development process of real economy and social entities through the congenital advantages. Among them, the convenience of service in people's daily life can make people enjoy the development of the Internet industry and constant convenience. From the perspective of thought, Chinese teaching mode of college English should focus on the actual needs of Chinese college English teaching under the current thinking mode of "Internet plus" in the process of continuous innovation. And the thinking mode of "Internet plus" should be constantly integrated into college English teaching mode, which can enhance the teaching efficiency and teaching quality of our college English teaching.

\section{Current Existing Problems of English Teaching in Colleges and Universities Under the Background of "Internet Plus"}

\section{Rigid teaching idea}

There is an important problem in English teaching of current colleges and universities, which affects the spiritual activation of teaching under certain circumstances. At the same time, the Internet information age also has affected the continuous development of English education teaching in China. But Internet technology is moving faster and faster in terms of information, and the increasing speed is higher. In the era of Internet technology, people have to constantly adjust their mentality and the structure of the knowledge. And the constantly changing era has put forward higher new requirements with talents, which means that, in present market environment, if students want to be recognized in domestic job market after graduation, they should be timely update their thoughts and ideas, expand their knowledge .In addition, students are usually emphasized and asked to learn teaching contents of textbooks, which cannot help students apply knowledge into the practical life. And it is bad for students' planning.

\section{Stiff teaching model}

The important problem in the process of college English teaching in our country is the stiff teaching. In the traditional way of teaching, cramming teaching is still affecting those teachers of current Chinese colleges and universities. This so-called "cramming" teaching means that teachers impart the knowledge of books to the students by means of full-class pouring in class. It also requires that college students can quickly learn and recite relevant knowledge. By means of such teaching method, on the one hand, it will obliterate college students' enthusiasm and interest to learn English; on the other hand, the expansion of students' knowledge is also poor. Many Internet technologies can give students the corresponding data. And the content of English teaching is very suitable for college students. If teachers discard these teaching resources from Internet, it will cause a certain waste of resources to some extent, which is not conducive to college students' study.

3. Backward teaching content

Backward teaching content is the second problem. Language is a relatively broad and active subject. The language itself is undergoing transformation when students are learning the language. From this point of view, teachers should focus on the changes in the process of college English teaching and start from the practical condition and constantly update their own teaching content to keep pace with the era. But the analysis of actual situation in English teaching practice of domestic colleges indicated that teacher are occupied with scientific researches and relevant thesis writing tasks, so they often neglect to update their teaching content. Most of the time, quite a number of teachers hold the idea that English teaching with students is a task that has to be done, so they don't need to play a more subjective initiative to complete, which will also affect the updating speed of teaching content. 


\section{Solve the Problem Existing in College English Teaching Under the View of "Internet Plus".}

\section{Constantly updating teaching concepts}

We should adhere to a teaching concept in the current teaching process, namely, to constantly update the English teaching model. With the advent of the Internet, the teaching of "Internet plus" has been carried out, and Internet technology has been used by many teachers and students. It has become a necessity to a certain extent and also makes the students and teachers to use the Internet technology with more diverse ways. And the method of using Internet technology will be more convenient. The idea of constantly updating teaching content has become a necessity of life under the realistic condition. In the professional mind, teachers play a leading role in the teaching and education, and they should constantly expand their professional knowledge capacities and visions so as to achieve updating teaching ideas. The school should create sufficient conditions and opportunities for teachers to learn and continue to contact new things. And teachers should be more actively to take part in related training and managing BBS, thus improving their knowledge accumulation through reading literature and overseas study. It is necessary to strengthen the constitution of knowledge, so that they can constantly update the teaching concept and provide better teaching content for college students.

2. Appropriately adjust the teaching content

College teaching should constantly update the teaching mode under the background of "Internet plus education", on the basis of the continuous development of Internet technology. English has a wide range of application in daily life. At the same time, English teaching has also increased students' knowledge levels, among which the development of Internet technology has provided many opportunities for students and teachers to learn English. Also, the application of Internet technology can provide many convenient conditions for English teaching and learning. Viewing the long-term students from our China, English teachers should adjust their teaching content appropriately and provide continuous teaching resources according to Internet technology. Teachers should constantly adjust their teaching methods in the study and the communication and exchange with students to help students understand current forefront concept and methods of English learning. And they should help students learn the guidance method of English through constant learning to enhance the oral abilities in spoken English and make English become a truly meaningful tool. In the process of students' learning English, it is necessary to continuously master the skills to communicate with foreigners. And the ultimate goal is to conduct a series of activities such as business cooperation and cultural communication based on communication with foreign people. In order to get rid of the traditional teaching meaning in China, teachers should know how to transform the teaching content and use the "Internet plus education" to make their teaching goals.

3 Set new teaching goals

The corresponding teaching goal should be made through Internet technology in the teaching process of English. The goal of teaching should be based on the actual situation of teaching, which also helps the teacher to carry on the English teaching goal in certain circumstances and more emphasized in the teaching. However, in the actual situation, students tend not to focus on the classroom when reading. The role of teachers in the classroom is mainly a guiding process, so teachers can not reach the teaching objectives through the classroom. Therefore, teachers should constantly adjust their teaching objectives. In addition, they should help students to study and review the study plan under class, so that students can complete the learning and promotion of knowledge through Internet technology. To some extent, it helps students to improve their learning efficiency and helps students to complete teaching tasks, so that students can improve their English proficiency.

\section{Conclusion}

To sum up, English teaching and Internet technology should be continuously combined under the education era of "Internet plus". This will enable students to be more efficient in learning English and teachers should constantly change their teaching levels, objectives and ideas through Internet technology to constantly make corresponding innovation with their teaching. 


\section{Acknowledgements}

Research on classroom mode of initiaative-cooperative learning in vocational English teaching based on teaching experience in America. Supported by Sichuan vocational college of information technology (Grant No 2016(9)).

\section{References}

[1]. Li Fang. Research on college English teaching under the thinking mode of "Internet plus" [J]. English square,2018(04):86-87.

[2]. Haihua Han. Research on college English teaching under the background of "Internet plus" [J]. Crazy English (theoretical),2017(04):120-121.

[3]. Hongmei Fan. Study on the college English teaching mode from the perceptive of "Internet plus education"[J]. Time Education,2017(21):51.

[4]. Tao Guo. Research on English teaching strategies under the thinking mode of "Internet plus" [J]. Intelligence, 2017(31):115.

[5]. Xiaoying Zhai. Analysis of college English teaching under the thinking mode of "Internet plus" [J]. Crazy English (theoretical),2017(03):108-109. 